e-ISSN: 2623-0089

Website :

jurnal.umj.ac.id/index.php/baskara

Email : baskara@umj.ac.id

\title{
Factors Affecting Value of Companies (Case Study of the Indonesian Pharmaceutical Industry)
}

\author{
Harmaini \\ Faculty of Economy and Business, Universitas Trisakti \\ J1. Kyai Tapa No. 1 Grogol, Jakarta Barat, Indonesia \\ E-mail: harmainise01@gmail.com
}

\begin{abstract}
The pharmaceutical industry in Indonesia has good prospects in the future. With the outbreak of Covid 19, the pharmaceutical industry is increasingly important. Firm value reflects the ability of a company to return investment so as to convince investors to invest in the company. It leads us into question what has an impact on firm value. This study aims to determine and analyze the effect of firm size, solvency, and profitability on company assessment either simultaneously or partially. The population in this study were pharmaceutical companies listed on the Indonesia Stock Exchange for the period 2013 to 2018. The sample in this study was selected using a purposive sampling method which selected 7 companies from 12 companies that would be used as research objects. The data analysis method used is the panel data analysis method or a combination of cross sectional and time series. The research results obtained are simultaneously firm size, solvency, and profitability have an effect on firm value. Meanwhile, partially solvency and profitability have an effect on firm value. However, company size has no effect on firm value.
\end{abstract}

Keywords: Company Size, Solvency, Profitability

\section{INTRODUCTION}

The pharmaceutical industry in Indonesia has good prospects in the future. Starting in 2004 the government issued Law No. 40 on the National Social Security System (SJSN). Law No. 40 regulates the implementation of the SJSN which includes health insurance, work accident insurance, pension security, old age security, and death security for all residents through mandatory worker contributions which are managed by Badan Penyelenggara Jaminan Sosial Kesehatan (BPJS). BPJS, insurance and social security has had a positive and significant impact on the pharmaceutical industry in Indonesia.

With the outbreak of Covid 19, the pharmaceutical industry is increasingly important. The Indonesian pharmaceutical industry is able to meet $75 \%$ of domestic drug needs, the remaining $25 \%$ is imported from abroad (kemenperindo go.id). There are 206 companies engaged in the pharmaceutical sector. Consisting of 178 private companies, 24 multinational companies and 4 state-owned companies. Of the 206 companies, up to 2020, 12 pharmaceutical companies have become publicly listed companies and are listed on the Indonesia Stock Exchange (IDX) and are then categorized into the Consumer Goods Industry sector which is also known as the manufacturing sector.

Firm value reflects the ability of a company to return investment so as to convince investors to invest in the company. 
According to Wirianata (2019), high company value shows the success of company leaders and managers in achieving the company's main goals. This value is reflected in the increasing stock market price, the stock market price shows the central assessment of all market players, which acts as a barometer of the company's management performance.

Companies that go public will provide benefits including: (i) increasing the value of a company, (ii) opening up company access to long-term funding facilities, (iii) increasing the company's image, (iii) growing the loyalty of company employees, (iv) the ability to maintain business continuity and (v) tax incentives. The main factor that investors see in investing in shares in publicly traded companies is financial statements, which according to Kieso (2019) are information that is expected to be able to provide assistance to users to make financial economic decisions.

There are four ways that can be used in assessing company performance with financial ratios, namely: profitability financial ratios, solvency financial ratios, liquidity financial ratios and activity financial ratios. The solvency ratio is a financial ratio that is used to determine the size of the company's funding from the use of debt. If the solvency ratio is good it will affect

Public trust (especially shareholders and investors who want to put their funds into the company) so that the size of the company value is high. According to (Luthfiana, 2018) the financial ratio of profitability also affects the value of the company by calculating the profit obtained by the company. This ratio is usually used to obtain the level of effectiveness of company management (Surmadewi \& Saputra, 2019). The higher the profitability value, the better the company's future opportunities to develop, causing investors and shareholders to have the confidence to invest funds in the company. (Fitriani, 2010) states that profitability has a positive and significant significance towards firm value.

According to Gultom (2013), company size can affect firm value. The larger the size of the company, the easier it will be for the company to obtain sources of funding, both internal and external, so that companies tend to have more sources of funds to support its operational activities. Thus the company gets more opportunities to earn higher profits

\section{THEORETICAL FRAMEWORK Agency Theory}

Agency theory explains the importance of company owners (shareholders) called the Principal delegating the authority to manage the company to agents (management) as professionals. The objective is to separate the owner and manager so that the company is run by a professional person in the hope of generating maximum profit.

The negative impact of this separation is the occurrence of complict interest between the principal (company owner) and the agent (manager). The freedom of company management in maximizing profits leads to the process of maximizing the interests of the managers themselves by imposing costs on the company (Nuraeni, Mulyati, \& Putri, 2018). Another impact of this separation is the emergence of asymmetric information in terms of the use of funds by company managers. as well as the right balance between existing interests, for example between shareholders and company management, and between majority shareholders and minority shareholders (Jensen \& Meckling, 1976), states that: "There are two mechanisms to resolve agency conflicts, namely the mechanism binding (bonding) and monitoring mechanisms (monitoring) ". This study focuses on the supervisory mechanism that is closely related to financial reports.

Principals must pay agency costs, namely controlling costs to limit 
management actions to suit the principal's interests (Wimelda \& Siregar, 2017). High agency costs illustrate the disharmony of the relationship between the principal and the agent. Conversely, the lower the agency costs, the more optimal the relationship between the principal and the agent (Wimelda \& Siregar, 2017). If agency costs are low, it will encourage the increase in firm value (Manurung et al., 2014).

\section{Signaling Theory}

Signaling theory provides the understanding that information provided by management to outsiders will be a signal for the market. Good signals will be responded to well by other parties. According to Brigham and Houston (2010), a signal is an act of company management, which provides instructions for investors about how management sees the company's prospects. A good financial report is a signal or a sign that the company has also been operating well (Sunardi, 2010). According to Zainudin and Hartono (1999), information published as an announcement will provide a signal for investors in making investment decisions. Information on the amount of assets that reflects the size of the company, the level of leverage, the amount of audit fees, and sales, which is contained in the report on the results of management accountability or internal parties for its performance in the company are a signal of management regarding the company's ability to generate profits. Companies can improve earnings quality by reducing information asymmetry, namely by providing signals to outsiders, one of which is in the form of positive and reliable financial information that will reduce uncertainty about future prospects. The value of the company. Company value is a value that can be used to measure how much the "Importance Level" of a company is seen from the point of view of several parties such as investors who relate the value of a company to its share price. by maximizing the share price and that is also what the owner of the company wants because high company value indicates high shareholder prosperity.

$$
P E R=\frac{\text { Current stock market price }}{\text { Earnings per share }(\text { EPS })}
$$

Company Size. According to Riyanto (2015) "The size of the company is seen from the amount of equity value, sales value or asset value". Hansen and Juniarti (2014), company size is measured by the size of the company's total sales, company assets, the average level of company sales, and the average total assets owned by the company. (Luthfiah \& Suherman, 2018), stated that the size of the company can be seen from the total assets of the company that can be used in the company's operating activities.

Company size can be categorized into large companies, medium companies, and small companies (Susanti \& Restiana, 2018). Companies with large total assets have the ability to use all these assets in maximizing company profits so as to provide a high rate of return for shareholders. Companies with large total assets are also more flexible and easier to obtain funds from external companies. With the increase in company size, investors will give a positive response and will increase the value of the company (Salim and Susilowaty, 2019).

Company size is a way of classifying business entities on the basis of their total assets. The asset base is used according to Kurniasih (2013) because of the level of stability that is related to it.

The firm size measurement is formulated as follows:

Business entity size $=$ Ln Total Assets

Solvency Ratio or Leverage Ratio is a ratio that describes the company's capability to pay off all debts / liabilities. This ratio is necessary for financial risk analysis. A company can be said to have good solvency as long as the company has sufficient assets to pay off all its debts, on the other hand, if 
the solvency is not good, the company does not have sufficient assets to settle its debts.

$$
D E R=\frac{\text { Total Debt }}{\text { Total Equity }} \times 100 \%
$$

Profitability is the level of net profit that can be obtained by a company from its operational activities, where the profits are distributed to shareholders in the form of dividends, and the profits can also be saved and used to improve the performance of operational activities. In this study using ROE (Return on Equity). This ratio represents the contribution of equity in making net income, which can also be used as a measure for the rate of return on funds of both investors and common stockholders. It can be said that ROE pays attention to the effectiveness of management in managing funding sources of funds effectively to create net income and show the benefits that will be enjoyed by investors. According to Azhar, et al. (2017) ROE indicates that the company has a competitive advantage over a long period of time and the investment of shareholders in the form of capital will increase in the next year which can refer to the high share price in the future. This can cause many investors to want to invest in the company, in addition to increasing share prices, the company's value also increases.

$$
\mathrm{ROE}=\frac{\text { Net profit }}{\text { Net sales }} x 100 \%
$$

\section{Previous Research}

The review of previous researchers is attached below.

\begin{tabular}{|c|c|c|c|c|}
\hline $\begin{array}{l}\text { Researcher } \\
\text { Name }\end{array}$ & Year & Research title & Variable Used & $\begin{array}{l}\text { The Results } \\
\text { Obtained }\end{array}$ \\
\hline $\begin{array}{l}\text { Gultom, } \\
\text { Robinhot } \\
\text { Wijaya, } \\
\text { Widia }\end{array}$ & 2013 & $\begin{array}{l}\text { Analysis of the } \\
\text { factors that affect } \\
\text { the value of the } \\
\text { company in } \\
\text { pharmaceutical } \\
\text { companies on the } \\
\text { Indonesia stock } \\
\text { exchange }\end{array}$ & $\begin{array}{l}\text { Dependent Variable: } \\
\text { Firm Value (PER) } \\
\text { Independent Variable: } \\
\text { Capital structure (DER), } \\
\text { Liquidity } \quad \text { (CR) Firm } \\
\text { Size t Profitability } \\
(\mathrm{NPM})\end{array}$ & $\begin{array}{l}\text { Simultaneously: } \\
\text { there is an influence } \\
\text { between capital } \\
\text { structure, liquidity, } \\
\text { firm size and } \\
\text { profitability on firm } \\
\text { value. } \\
\text { Partially: the } \\
\text { profitability variable } \\
\text { has a significant } \\
\text { effect on firm value, } \\
\text { but the capital } \\
\text { structure, liquidity } \\
\text { and firm size } \\
\text { variables do not have } \\
\text { a significant effect } \\
\text { on firm value. }\end{array}$ \\
\hline $\begin{array}{ll}\text { Pratama, A } & \text { A } \\
\text { Bagus Angga } & \\
\text { Wiksuana, } & \text { I } \\
\text { Gusti Bagus } & \end{array}$ & 2018 & $\begin{array}{l}\text { Effect of Firm Size } \\
\text { and Profitability on } \\
\text { Firm Value with } \\
\text { Capital Structure as } \\
\text { a mediating } \\
\text { variable }\end{array}$ & $\begin{array}{l}\text { Dependent Variable: } \\
\text { The value of the } \\
\text { company } \\
\text { Independent Variable: } \\
\text { Firm Size, Profitability } \\
\text { Mediation Variables: } \\
\text { Capital Structure }\end{array}$ & $\begin{array}{llr}\text { Company } & \text { Size and } \\
\text { Capital } & \text { Structure } \\
\text { have a significant } \\
\text { positive effect on } \\
\text { Firm Value. }\end{array}$ \\
\hline
\end{tabular}

\section{Table 1. Review of Previous Researchers}




\begin{tabular}{|c|c|c|c|c|}
\hline & & & & $\begin{array}{l}\text { Profitability has a } \\
\text { significant negative } \\
\text { effect on Firm Value } \\
\text { Capital Structure is } \\
\text { able to mediate the } \\
\text { effect of Firm Size } \\
\text { on Firm Value. } \\
\text { Capital Structure is } \\
\text { not able to mediate } \\
\text { the effect of } \\
\text { Profitability on Firm } \\
\text { Value }\end{array}$ \\
\hline $\begin{array}{l}\text { Luthfiana, } \\
\text { Azizah }\end{array}$ & 2018 & $\begin{array}{l}\text { The Effect of } \\
\text { Solvency, } \\
\text { Profitability and } \\
\text { Liquidity on Firm } \\
\text { Value "(Empirical } \\
\text { Study of Property } \\
\text { and Real Estate } \\
\text { Companies Listed } \\
\text { on the Indonesia } \\
\text { Stock Exchange } \\
\text { 2014-2017 Period) }\end{array}$ & $\begin{array}{l}\text { Dependent Variable: } \\
\text { The value of the } \\
\text { company } \\
\text { Independent Variable: } \\
\text { Solvency, Profitability } \\
\text { and Liquidity }\end{array}$ & $\begin{array}{l}\text { Simultaneously and } \\
\text { Partially: } \\
\text { Solvency, } \\
\text { probability, and } \\
\text { liquidity have a } \\
\text { positive and } \\
\text { significant effect on } \\
\text { Firm Value }\end{array}$ \\
\hline Alvianto, Axel & 2018 & $\begin{array}{l}\text { The Influence of } \\
\text { Capital Structure, } \\
\text { Company Growth } \\
\text { and Profitability on } \\
\text { Firm Value } \\
\text { Empirical Studies } \\
\text { on Manufacturing } \\
\text { Companies on the } \\
\text { Indonesia Stock } \\
\text { Exchange 2013- } \\
2016 "\end{array}$ & $\begin{array}{l}\text { Dependent Variable: } \\
\text { The value of the } \\
\text { company } \\
\text { Independent Variable: } \\
\text { Capital Structure, } \\
\text { Company Growth and } \\
\text { Profitability }\end{array}$ & $\begin{array}{l}\text { Simultaneously the } \\
\text { capital structure, } \\
\text { company growth and } \\
\text { profitability have an } \\
\text { effect on firm value. } \\
\text { Partially: capital } \\
\text { structure and } \\
\text { profitability have an } \\
\text { effect on firm value, } \\
\text { while firm growth } \\
\text { has no effect on firm } \\
\text { value. }\end{array}$ \\
\hline $\begin{array}{l}\text { Wirianata, } \\
\text { Henny }\end{array}$ & 2019 & $\begin{array}{l}\text { Factors Affecting } \\
\text { Firm Value With } \\
\text { GCG Moderation }\end{array}$ & $\begin{array}{l}\text { Dependent Variable: } \\
\text { The value of the } \\
\text { company } \\
\text { The independent } \\
\text { variables of capital } \\
\text { structure, profitability, } \\
\text { firm size, firm size, and } \\
\text { GCG with institutional } \\
\text { ownership have a } \\
\text { negative and significant } \\
\text { effect on firm value. } \\
\text { Moderation variable: }\end{array}$ & $\begin{array}{l}\text { Capital structure } \\
\text { (DER), profitability, } \\
\text { have a positive and } \\
\text { significant effect on } \\
\text { firm value } \\
\text { company size, and } \\
\text { GCG with } \\
\text { institutional } \\
\text { ownership have a } \\
\text { negative and } \\
\text { significant effect on } \\
\text { firm value. }\end{array}$ \\
\hline
\end{tabular}




\begin{tabular}{|l|l|l|} 
good corporate & $\begin{array}{l}\text { Institutional } \\
\text { governance (GCG) } \\
\text { ownership cannot } \\
\text { moderate the effect } \\
\text { of capital structure, } \\
\text { profitability, and } \\
\text { firm size on firm } \\
\text { value }\end{array}$
\end{tabular}

\section{Conceptual Framework}

The contents of the conceptual variables which will be indicated to affect framework of the three independent the dependent variable.

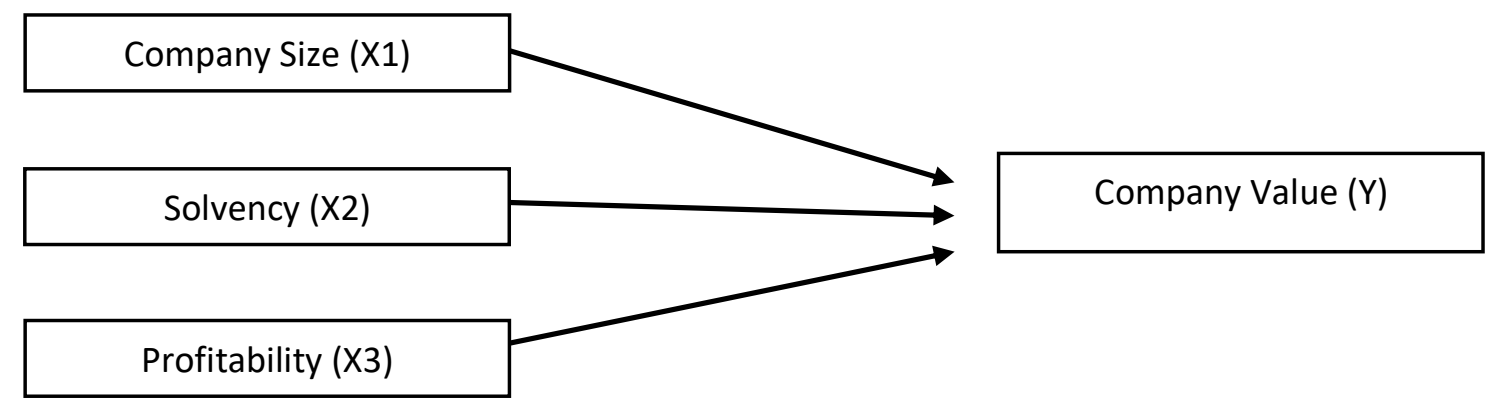

Figure 1. Conceptual Framework

Based on the theoretical study that has been described, the hypothesis that can be made for this study is company size, solvency and profitability have a simultaneous or partial effect on the value of pharmaceutical companies for the period 2013-2018.

\section{RESEARCH METHODS Population and Sample}

The population in this study were 12 publicly listed pharmaceutical companies listed on the IDX from 2013 to 2018. The method of determining the sample used was purposive sampling, which is a sample that has the following criteria:

a. Pharmaceutical companies listed on the IDX from 2013 to 2018. b. Pharmaceutical companies that publish financial report data consecutively from 2013 to 2018, whether audited or unaudited.

There were 7 companies sampled. The data used is secondary data, which is generally in the form of evidence, records, or historical reports that have been compiled in archives (documentary data). Secondary data in this study were obtained from several websites such as: www.idx.co.id, www.sahamok.com, www.bei5000.com

\section{Operational Definition of Variables and} Variable Measurement Methods

The operational definition of variables and variable measurement methods

Can be seen below 
Table 2. Operational Definition of Variables and Variable Measurement Methods

\begin{tabular}{|c|c|c|c|}
\hline Variabel & Variable Definitions & Parameter & $\begin{array}{l}\text { Measurement } \\
\text { Scale }\end{array}$ \\
\hline \multicolumn{4}{|l|}{$\begin{array}{l}\text { Variabel } \\
\text { Dependent }\end{array}$} \\
\hline Firm Value (PBV) & $\begin{array}{l}\text { The value of a } \\
\text { company that can be } \\
\text { measured from the } \\
\text { company's current } \\
\text { stock price }\end{array}$ & $\begin{array}{l}\text { PBV }=\frac{\text { Current Share Price }}{\text { Earnings per share }} \\
\text { Sources: Robinhot, } \\
\text { Agustina, and Sri Widia. } \\
2013\end{array}$ & Ratio \\
\hline \multicolumn{4}{|l|}{$\begin{array}{l}\text { Variabel } \\
\text { Independen }\end{array}$} \\
\hline $\begin{array}{l}\text { Company } \\
\text { (LNTS) }\end{array}$ & $\begin{array}{l}\text { The size of a company } \\
\text { is measured by the total } \\
\text { assets it owns }\end{array}$ & $\begin{array}{l}\text { Company size }=\text { Ln (total } \\
\text { assets) Sources: } \\
\text { Robinhot, Agustina, and } \\
\text { Sri Widia. 2013 }\end{array}$ & Ratio \\
\hline Solvency (DER) & $\begin{array}{l}\text { comparison of the use } \\
\text { of funds through debt } \\
\text { versus own capital }\end{array}$ & $\begin{array}{l}D E R= \\
\frac{\text { Total Debt }}{\text { Total Equity }} \times 100 \% \\
\text { Permatasari } \\
\text { Azizah,(2018). }\end{array}$ & Ratio \\
\hline Profitability (ROE) & $\begin{array}{l}\text { Profits derived from } \\
\text { the } \\
\text { operations }\end{array}$ & $\begin{array}{l}\text { ROE }=\frac{\text { Net profit }}{\text { Net Sales }} x 100 \% \\
\text { Surmadewi and Saputra, } \\
\text { 2019). }\end{array}$ & Ratio \\
\hline
\end{tabular}

\section{Data Analysis Methods}

This study uses quantitative methods in analyzing the influence of firm size, solvency and profitability on firm value. The data obtained will be analyzed using statistical programs, namely Eviews 9.5 and Microsoft Excel program. The data source that will be used is secondary data from the Indonesia Stock Exchange (IDX), then the object is a pharmaceutical company listed on the Indonesia Stock Exchange (IDX) in
2013 - 2018. Data taken are panel data or a combination of cross sectional and time series (periodically).

\section{RESULTS AND DISCUSSION \\ Descriptive Statistics}

With descriptive statistical analysis, the maximum and minimum values of each variable can be described and can compare the average value with standard deviation to see whether the data is well distributed or not. 
Table 3. Descriptive Statistics of Research Variables, 2013-2018

\begin{tabular}{|l|l|l|l|l|}
\hline & PBV & LNTS & DER & ROE \\
\hline Mean & 3.364095 & 20.51538 & 0.474119 & 0.149500 \\
\hline Maximum & 8.785000 & 29.87814 & 1.819000 & 0.301000 \\
\hline Minimum & 0.568000 & 14.84374 & 0.071000 & 0.028000 \\
\hline Std. Dev. & 1.913416 & 5.041915 & 0.369067 & 0.066630 \\
\hline Observations & 42 & 42 & 42 & 42 \\
\hline
\end{tabular}

Based on the test in table 3 above, it can be seen that $\mathrm{n}$ or the total number of each variable is 42 from 7 samples of pharmaceutical companies that have been listed on the IDX for the period 2013 to 2018. The company value variable (PBV) shows a minimum value of 0.568 in 2015 owned by PT Pyridam Farma Tbk (PYFA) and with a maximum value of 8,785 owned by PT. Kalbe Farma Tbk (KLBF) in 2014, meaning that the higher the PBV value, the higher a company is considered by investors, on the contrary, the lower the PBV value, the lower the company will be assessed by investors. The average PBV of 42 observations is 3,364 with a standard deviation of 1.9134, which means the data is well distributed because the deviation rate is smaller than the average value.

The company size variable is in Table 3 shows a minimum value of 14.84374 , which is owned by the company PT. Sido Muncul Tbk (SIDO) in 2015 and a maximum value of 29,87814 owned by PT.Kimia Farma (Persero) Tbk (KAEF) Tbk in 2018. The average value of the company size from 42 observations was 20,51538 with a standard deviation of 5.041915 , indicating that the data is distributed with good because the deviation rate is smaller than average.

The lowest solvency value (DER) is 0.071 owned by PT Industri Jamu and Pharmaceuticals Sido Muncul Tbk (SIDO) in 2014 which means that the lower the debt policy, the lower the company's ability to pay its debts using existing equity or capital. . Then for the maximum value is
1,819 owned by PT Kimia Farma (Persero) Tbk (KAEF) in 2018, this shows that the higher the debt policy, the higher the company's ability to pay its debts using existing equity or capital. The average DER of the 42 observations is 0.4741 with a standard deviation of 0.3690 , the data is well distributed because the average is higher than the standard deviation.

The ROE (Profitability) variable has a minimum value of 0.028 owned by PT Pyridam Farma Tbk (PYFA) in 2014 which shows that the company cannot provide high returns on return on equity. The maximum value of 0.301 is owned by PT Merck Tbk (MERK) in 2015, meaning that the greater the ROE shows that the company can provide high returns on return on equity. The average ROE of the 42 observations is 0.1495 with a standard deviation of 0.0666 , which means that the data is well distributed because the average is greater than the standard deviation.

\section{Model Selection}

There are several model selection which can be applied which are Chow Test (Pool Least Square or Fixed Effect).

Chow Test (Pool Least Square or Fixed Effect) or Chow Test is conducted to determine the Common Effect and Fixed Effect Model (FEM) model (with no weighting procedure) which will be selected for data estimation, then it will be carried out with a restricted F-test. The following is the processed result with the help of Eviews 9.5 from the restricted F-test: 
Table 4. Test Results of the Restricted F-test

\begin{tabular}{lllll}
\hline \hline Effects Test & Statistic & d.f. & Prob. \\
\hline \hline Cross-section F & 11.892227 & & $(6,32)$ & 0.0000 \\
Cross-section Chi-square & 49.241553 & 6 & & 0.0000
\end{tabular}

Source: Data processed by Eviews 9.5

$\mathrm{H}_{0}$ : Model estimation can be used in model estimation with the Common Effect Model.

$\mathrm{H}_{\mathrm{a}}$ : Estimation model can be used model estimation with Fixed Effect Model (FEM).

Decision making by comparing the probability of the F-count with $\alpha_{0,05}$ :

If the Probability of F-count > 0,05, then $\mathrm{H}_{0}$ is accepted.

If the Probability of F-count $<0,05$, then $\mathrm{H}_{0}$ is rejected.

From the calculation of the restricted F-test, $\mathrm{H}_{0}$ is accepted and $\mathrm{Ha}$ is rejected, this is because the probability of the F- count is 0.0000 smaller than 0.05 , so it proves that the Fixed Effect Model is more appropriate because the model has individual effects, meaning that each -Each individual (the company studied) has their own intercept, meaning that the estimation model is the most appropriate estimation using the Fixed Effect Model.

The next step is to conduct a specification test using the Hausman test. This test aims to find the right and more efficient model between the Fixed Effect Model (FEM) or the Random Effect Model (REM). The following is the processed Hausman test with the help of the Software Views 9.5:

Table 5. Hausman Test Results

\begin{tabular}{llll}
\hline \hline Test Summary & $\begin{array}{l}\text { Chi-Sq. } \\
\text { Statistic }\end{array}$ & Chi-Sq. d.f. & Prob. \\
\hline \hline Cross-section random & 0.343137 & 3 & 0.9517 \\
\hline \hline
\end{tabular}

Sources: The data is processed by Eviews 9.5

$\mathrm{H}_{0}$ : Fixed Effect Model (FEM) is not appropriate to use and Random Effect Model (REM) is the right and more efficient model.

Ha: The Random Effect Model (REM) is not appropriate to use and the Fixed Effect Model (FEM) is the right and more efficient model.

Decision making by comparing the probability of the Chi-Square Statistics with $\alpha_{0,05}$ :

If the Probability of Chi-Square Statistics> 0.05, then HO is accepted.

If the Probability of Chi-Square Statistics $<0.05$, then $\mathrm{HO}$ is rejected.
Based on the table of Hausman test results, $\mathrm{H}_{0}$ is accepted, this is because the probability value of the Chi-Square Statistics is $0.9517>0.05$ proves that the Fixed Effect Model (FEM) is not appropriate to use and the Random Effect Model (REM) is the right model and more efficient

The next step is to conduct a specification test using the Lagrange Multiplier Test or LM Test. This test aims to find the right and more efficient model between the Random Effect Model (REM) or the Common Effect Model. The following are the processed results of the 
LM Test with the help of the Views 9.5 software:

Table 6. LM Test Results for Random Effects

Null hypotheses: No effects

Alternative hypotheses: Two-sided (Breusch-Pagan) and onesided

(all others) alternatives

\begin{tabular}{cccc}
\hline \hline & \multicolumn{3}{c}{ Test Hypothesis } \\
& Cross-section & Time & Both \\
\hline \hline \multirow{2}{*}{ Breusch-Pagan } & 39.73171 & 0.893709 & 40.62542 \\
& $(0.0000)$ & $(0.3445)$ & $(0.0000)$ \\
\hline \hline
\end{tabular}

Sources: The data is processed by Eviews 9.5

$\mathrm{H}_{0}$ : The Random Effect Model (REM) is not appropriate to use and the Common Effect Model is the right and more efficient model.

$\mathrm{H}_{\mathrm{a}}$ : The Common Effect Model is not appropriate to use and the Random Effect Model (REM) is the right and more efficient model.

Decision making by comparing the probability of the Chi-Square Statistics with $\alpha_{0,05}$ :

If the Probability of Chi-Square Statistics $<0.05$, then $\mathrm{H}_{0}$ is rejected.

If the Probability of Chi-Square Statistics> 0.05, then $\mathrm{H}_{0}$ is accepted.

From the results of the LM test, it rejects $\mathrm{H} 0$ and accepts $\mathrm{Ha}$, this means that the Bruesch-Pagan Cross-Section probability value has a significance value of 0.0000 which is smaller than 0.05 , proving that the Common Effect Model is not appropriate to use and the Random Effect Model (REM) is the right model and more efficient.

From the panel data selection test, it can be concluded that the Random Effect Model is the best method. This can be seen from the Restricted F-Test which produced the Fixed Effect Model as the best method, the Hausman Test which produced the Random Effect Model as the best method, and the LM Test which produced the Random Effect Model as the best method.

This test calculates the level of the model in explaining the type of the dependent variable (Ghozali 2011, in Wiguna 2016). If the $\mathrm{R}^{2}$ value is low, then the ability of the independent variable to explain a certain dependent. The coefficient of determination in this study is seen from the Adjusted R-Square. The variation in the value of the independent variable, namely firm size, solvency and profitability, is able to explain the dependent variable Firm Value by 33.60 percent and the remaining 66.40 percent is influenced by other factors not included in this study.

Data analysis obtained from the results of testing the hypothesis. Hypothesis testing is used to see whether there is an influence between LNTS, DER and ROE on PBV. To test the hypothesis, the $\mathrm{t}$ statistical test is carried out, namely whether one independent variable individually can influence the dependent variable or not by assuming the other variables are constant.

Basis for decision making: If the $\mathrm{p}$-value $<\alpha_{0,05}$ then $\mathrm{H}_{0}$ was rejected. If the $\mathrm{p}$-value $>\alpha_{0,05}$ then $\mathrm{H}_{0}$ was accepted.

After conducting several tests, the interpretation of the study results for this research is as follows: 
Table 7. Regression Panel Test Results

\begin{tabular}{lllll}
\hline \hline Variable & Coefficient & \multicolumn{2}{l}{ Std. Error t-Statistic } & Prob. \\
\hline \hline C & 0.451227 & 3.411050 & 0.132284 & 0.8955 \\
LNTS & -0.065080 & 0.175582 & -0.370655 & 0.7130 \\
DER & 2.180461 & 0.825057 & 2.642799 & 0.0119 \\
ROE & 21.49977 & 4.291663 & 5.009658 & 0.0000 \\
\hline \hline
\end{tabular}

Effects Specification

\begin{tabular}{lll} 
& S.D. & Rho \\
\hline \hline Cross-section random & 1.824088 & 0.7823 \\
Idiosyncratic random & 0.962314 & 0.2177 \\
\hline \hline
\end{tabular}

Weighted Statistics

$\begin{array}{lr}\text { R-squared } & 0.384542 \\ \text { Adjusted R-squared } & 0.335953 \\ \text { F-statistic } & 7.914199 \\ \text { Prob(F-statistic) } & 0.000319\end{array}$

Source: Data processed by Eviews 9.5

Based on Table 7 above, the regression equation between LNTS, DER and ROE on PBV is obtained.

PBV $=0.451227-0.065080$ LNTS + 2.180461 DER + 21.49977 ROE

Information:

1. A constant value of 0.451227 indicates that the company value is 0.451227 if the other independent variables are considered constant.

2. The variable company size (LNTS) is -0.065080 . This indicates that if the company size value increases by one unit, the firm value will decrease by 0.065080 units, assuming the other independent variables are constant.

3. The Solvency variable (DER) is worth 2.180461. This shows that if the solvency value increases by one unit, the firm value will increase by 2.180461 units, assuming the other independent variables are constant.

4. The variable Profitability (ROE) is worth 21.49977. This shows that if the value of Profitability increases by one unit, the company value will increase by 21.49977 units, assuming the other independent variables are constant.

There are four hypothesis regarding this matter which are mentioned below:

1. Hypothesis 1: Effect of LNTS ratio on PBV.

Based on the table above, it is known that the LNTS variable has a negative beta coefficient of 0.065080 for PBV and a 1-tailed $\rho$ value (sig.) Of $0.7130>0.05$. Coefficient value $\beta 1$ which has a negative value of -0.065080 means that an increase in LNTS by 1 will decrease the PBV by 0.065080 units. $\mathrm{H} 01$ failed to be rejected due to sig. $>0.05$ so that the hypothesis 1 test cannot be supported, then LNTS has no effect on PBV.

2. Hypothesis 2: Effect of the DER ratio on $\mathrm{PBV}$ 
Based on the table above, it is known that the DER variable has a positive beta coefficient of 2.180461 against PBV and a 1-tailed $\rho$-value (sig.) Of $0.0119<0.05$. Coefficient value $\beta 2$ which has a positive value of 2.180461 means that an increase in DER by 1 will increase PBV by 2.180461 units. $\mathrm{H} 02$ was rejected due to sig. $<0.05$ so that the hypothesis 2 test can be supported, then DER has an effect on PBV.

3. Hypothesis 3: Effect of the ROE ratio on $\mathrm{PBV}$

Based on the table above, it is known that the ROE variable has a positive beta coefficient of 21.4997 against PBV and a 1-tailed $\rho$-value (sig.) Of $0.0000<0.05$. Coefficient value $\beta 3$ which has a positive value of 21.4997 means that an increase in ROE of 1 will increase the PBV of 21.4997 units. H03 is rejected due to sig. $<0.05$ so that the hypothesis 3 test can be supported, then ROE has an influence on PBV.

Hypothesis testing is simultaneously carried out by using the $\mathrm{F}$ test (Simultaneous Test). This test aims to determine the significant relationship between the dependent and independent variables as a whole. The following are the results:

Table 8. Simultaneous Test Results (Test F)

\begin{tabular}{|l|l|}
\hline F- Statistic & Prob. F-Statistic \\
\hline 7.914199 & 0.000319 \\
\hline
\end{tabular}

Source: Data processed by Eviews 9.5

Table 8 shows the results of the $F$ test (simultaneous test) which can be concluded that together the independent variables namely Company Size, Solvency and Profitability affect the dependent variable, namely Firm Value is significantly shown by Prob. F-Statistic $<0.05$.
Partial test or $\mathrm{t}$ Test shows how much influence the independent variable individually has on the dependent variable and to test the regression coefficient individually by comparing the level of significance. The following are the results with the weighting (cross-section weight) of each variable:

Table 9. Partial Test Results (t test)

\begin{tabular}{|c|c|c|c|c|}
\hline Variable & Coefficient & Std. Error & $\mathrm{t}$-Statistic & Prob. \\
\hline $\mathrm{C}$ & 0.451227 & 3.411050 & 0.132284 & 0.8955 \\
\hline LNTS & -0.065080 & 0.175582 & -0.370655 & 0.7130 \\
\hline DER & 2.180461 & 0.825057 & 2.642799 & 0.0119 \\
\hline ROE & 21.49977 & 4.291663 & 5.009658 & 0.0000 \\
\hline
\end{tabular}

Source: Data processed by Eviews 9.5

Based on the results of the t-test in table 8, in this study it can be concluded that: a. Company Size (LNTS)
From the test results above, it can be concluded that firm size has no effect on firm value because the probability t-statistic 
firm size (LNTS) is 0.7130 , greater than $\alpha$ (0.05).

b. Solvency (DER)

From the test results above, it can be concluded that Solvency has an influence on Firm Value because the probability of tStatistic Solvency, which is 0.0119 is smaller than $\alpha(0.05)$.

c. Profitability (ROE)

From the test results above, it can be concluded that Profitability has an influence on Firm Value because the probability of t-Statistic Profitability is 0.0000 smaller than $\alpha(0.05)$.

From the results of the data analysis obtained from the results of testing the hypothesis. Hypothesis testing is used to see whether there is an influence between LNTS, DER and ROE on PBV. To test the hypothesis, the $\mathrm{t}$ statistical test is carried out, namely whether one independent variable individually can influence the dependent variable or not by assuming the other variables are constant.

Basis for decision making:

If the $\mathrm{p}$-value $<\alpha_{0,05}$ then Ho was rejected.

If the $\mathrm{p}$-value $>\alpha_{0,05}$ then Ho was accepted.

\section{Interpretation of Results}

After conducting several tests, the interpretation of the study results for this research can be seen on the following table

Table 10. Regression Panel Test Results

\begin{tabular}{|c|c|c|c|}
\hline Variable & Coefficient Std. Error & $\mathrm{t}$-Statistic & Prob. \\
\hline $\mathrm{C}$ & $0.451227 \quad 3.411050$ & 0.132284 & 0.8955 \\
\hline LNTS & $-0.065080 \quad 0.175582$ & -0.370655 & 0.7130 \\
\hline DER & $2.180461 \quad 0.825057$ & 2.642799 & 0.0119 \\
\hline \multirow[t]{3}{*}{ ROE } & $21.49977 \quad 4.291663$ & 5.009658 & 0.0000 \\
\hline & \multirow[t]{2}{*}{ Effects Specification } & & \\
\hline & & S.D. & Rho \\
\hline \multirow{2}{*}{\multicolumn{2}{|c|}{$\begin{array}{l}\text { Cross-section random } \\
\text { Idiosyncratic random }\end{array}$}} & 1.824088 & 0.7823 \\
\hline & & 0.962314 & 0.2177 \\
\hline & \multicolumn{3}{|l|}{ Weighted Statistics } \\
\hline R-squared & \multicolumn{3}{|l|}{0.384542} \\
\hline Adjusted R-squared & \multicolumn{3}{|l|}{0.335953} \\
\hline F-statistic & \multicolumn{3}{|l|}{7.914199} \\
\hline Prob(F-statistic) & \multicolumn{3}{|l|}{0.000319} \\
\hline
\end{tabular}

Source: Data processed by Eviews 9.5

Based on the table 10 above, the regression equation between LNTS, DER and ROE on PBV is obtained.

$\mathrm{PBV}=0.451227-0.065080$ LNTS + 2.180461 DER + 21.49977 ROE

The constant variable in the table in this study explains that the constant value obtained for all research sample companies is 0.451227, which means that if all independent variables are zero then the average PBV will increase by 0.451227 .

\section{Discussion of Research Results}

In this study, an analysis was carried out to test the variables of Company Size Solvency and Profitability on the company 
value of 7 companies that were included in the pharmaceutical sub-sector listed on the Indonesia Stock Exchange in 2013-2018. So that each variable can be concluded as follows.

Based on the tests conducted in this study, it shows that firm size has no significant effect on firm value. From the results of the data in table 4.8 , it is found that the value of t-statistic and a negative coefficient value with a significance of less than $\alpha 0.05$, it can be concluded that company size negatively affects firm value, meaning that if the company size increases by one unit, there will be a decrease in firm value. of 0.065080 units with the assumption that other independent variables are constant. This is in accordance with the results of research by Gultom et al. (2013) using data for the years 2008-2011. This means that in assessing company investors do not care about the size of the company, the most important thing is that the company is able to generate high value their share price.

Based on the tests carried out in this study, it shows that the solvency represented by the Debt Equity to Ratio (DER) has an effect on firm value. From the results of the data in table 8 that there is a tstatistic value and a positive coefficient value with a significance less than $\alpha 0.05$, it can be concluded that solvency affects firm value positively, so the relationship with solvency to firm value has a positive effect on this study. The relationship between solvency and firm value has a positive effect. This means that if solvency increases by one unit, there will be an increase in company value. This is in line with research conducted by (Luthfiana, 2018) which states that solvency has an effect on firm value then explains that if the company's solvency ratio is good it will affect public confidence in a company. so that it can increase the value of the company.This result is also in accordance with the thradeoff theory by Myers which states that the company will be in debt to a certain level, where the tax assessment of additional debt equals the cost of difficulties. The higher the company makes funding using debt, the higher the burden that must be borne, so the greater the probability of bankruptcy. However, with the use of tax fees that must be paid by the company (tax deductible), it will produce a higher net profit to be distributed to shareholders (investors).

However, these results are not in line with research conducted by (Permana \& Rahyuda, 2019), which concluded in their research that the solvency represented by DER has a negative effect on firm value because the large amount of debt borne by the company can reduce the amount of profit received by the company because the company will try to better pay the obligations held. Small company profits will have an impact on the rate of return given to shareholders. Investors will reconsider investing so that the demand for company shares will decrease, and in the end it will affect the value of the company.

In this study, the Profitability variable has an effect on Firm Value. From the data in table 8 , it is found that the $\neg$-statistic value and a positive coefficient value with a significance of less than $\alpha 0.05$, it can be concluded that profitability affects firm value positively, hence the relationship between profitability and firm value. positive effect on this research. The relationship between profitability and firm value has a positive effect, meaning that if the profitability increases by one unit, there will be an increase in firm value. Profitability is assessing the level of a company that brings in how much profit it gets from its business activities through the resources used, namely from activities.

This result is also in line with the signal theory which explains that the profitability ratio stated in the financial statements is an effort to provide positive information / signals related to company performance and growth for the company's prospects in the future. This can build positive things for investors that can affect the increase in 
stock prices, which causes the company's value to increase as well.

This is in line with research conducted by (Alvianto, 2018), which concluded that profitability has a positive effect on firm value because if the profitability value increases, it indicates that the income received by the company is also higher, it also indicates that the company's ability to generate profits is also good. also results in investor confidence so as to increase demand for company shares so as to increase the value of the company.

\section{CONCLUSION}

The conclusion in this study is that simultaneously there is an influence between, company size, solvency and profitability on firm value in pharmaceutical companies listed on the IDX in 2013-2018. Meanwhile, partially, firm size has no significant effect on firm value. Solvency, profitability have a positive and significant effect on firm value.

The limitation of this study is that the research is only limited to pharmaceutical companies listed on the Indonesia Stock Exchange (BEI). The number of samples in this study were 7 pharmaceutical companies that had met the criteria. This research period is from 2013 to 2018 . This study only examines the effect of three independent variables on the dependent variable, namely company size, solvency and profitability on firm value. Suggestions for future researchers can include other variables that influence the development of research objects other than pharmaceutical companies such as manufacturing companies. Future studies are expected to extend the research period such as 10 years to obtain more accurate research results. In further research, it is hoped that it can add other variables that affect company value such as dividend policy because dividends distributed by companies tend to affect shareholders in investing which of course affect company value.

\section{REFERENCES}

Alvianto, A. (2018). Pengaruh Struktur Modal, Pertumbuhan Perusahaan dan Profitabilitas terhadap Nilai Perusahaan Studi Empiris pada Perusahaan Manufaktur di Bursa Efek Indonesia Tahun 2013-2016. Fakultas Ekonomi Universitas Sanata Darma.

Fitriani, L. (2010). Pengaruh Leverage, Ukuran Perusahaan Dan Profitabilitas Terhadap Nilai Perusahaan Pada Perusahaan Farmasi Yang Go Public Di BEI. Fakultas Ekonomi Universitas Negeri Padang.

Gultom, R., \& Wijaya, S. W. (2013). Analisis Faktor Faktor yang Mempengaruhi Nilai Perusahaan Farmasi di Bursa Efek Indonesia periode 2008-2011. Jurnal Wira Ekonomi Mikroskil, 3(1), 51-60.

Jensen, M. C., \& Meckling, W. H. (1976). Theory of the firm: Managerial behaviour, agency costs and ownership structure. Journal of Financial Economics, 3(4), 305-360.

Luthfiah, A. A., \& Suherman, S. (2018). The Effects Of Financial Performance Toward Firm Value With Ownership Structure As Moderating Variable (The Study On Manufacturing Companies Listed In Indonesia Stock Exchange In The Period Of 20122016). Journal of Business and Behavioural Entrepreneurship, 2(1), 18-27.

Luthfiana, A. (2018). Pengaruh Solvabilitas, Profitabilitas, dan Likuiditas Terhadap Nilai Perusahaan (Studi Empiris Pada Perusahaan Properti Dan Real Estate Yang Terdaftar Di Bursa Efek Indonesia Periode 2014-2017). S1 thesis, Fakultas Ekonomi UNY. 
Nuraeni, R., Mulyati, S., \& Putri, T. E. (2018). Faktor-faktor yang mempengaruhi persistensi laba (studi kasus pada perusahaan property dan real estate yang terdaftar di bursa efek indonesia tahun 2013-2015). ACCRUALS (Accounting Research Journal of Sutaatmadja), 2(1), 82-112.

Permana, A. A. N. B. A., \& Rahyuda, H. (2019). Pengaruh Profitabilitas, Solvabilitas, Likuiditas, Dan Inflasi Terhadap Nilai Perusahaan. E-Jurnal Manajemen, 8(3), 1577-1607.

Pratama, A. A. B. A., \& Wiksuana, I. G. B. (2018). Pengaruh Firm Size Dan Profitabilitas Terhadap Nilai Perusahaan Dengan Struktur Modal Sebagai Variabel Mediasi. E-Jurnal Ekonomi Dan Bisnis Universitas Udayana, 1289-1318.
Surmadewi, N. K. Y., \& Saputra, I. D. G. Dh. (2019). Pengaruh Likuiditas, Leverage, dan Profitabilitas Terhadap Nilai Perusahaan Pada Perusahaan Farmasi. E-Jurnal Ekonomi Dan Bisnis Universitas Udayana, 567-593.

Susanti, N., \& Restiana, N. G. (2018). What's the best factor to determining firm value. Jurnal Keuangan Dan Perbankan, 22(2), 301-309.

Wimelda, L., \& Siregar, S. V. (2017). The Effect of Financial Institution Ownership on Firm Value. Corporate Ownership and Control, 14(2), 114122.

Wirianata, H. (2019). Faktor-Faktor Yang Mempengaruhi Nilai Perusahaan Dengan Moderasi GCG. Jurnal Ekonomi, $24(3), \quad 468$. https://doi.org/10.24912/je.v24i3.610 